\title{
Prevalence of Cardiovascular Events in Patients with Autosomal Dominant Polycystic Kidney Disease
}

\author{
Imed Helal Berenice Reed Pamela Mettler Kim Mc Fann \\ Oleksandra Tkachenko Xiang-Dong Yan Robert W. Schrier \\ Division of Renal Diseases and Hypertension, University of Colorado Denver, Aurora, Colo., USA
}

\section{Key Words}

Autosomal dominant polycystic kidney disease •

Cardiovascular events · Risk factors

\begin{abstract}
Background: This study evaluates the prevalence of cardiovascular events in autosomal dominant polycystic kidney disease (ADPKD) patients. Methods: We distributed surveys to 1,439 subjects from our ADPKD research database. In total, 426 subjects completed and returned surveys; 7 of these were from children and were excluded from the study. $\boldsymbol{R} \boldsymbol{e}$ sults: The patients who responded were female (63.2\%), nonHispanic (88.1\%) and white (93.6\%). The mean age of the total group was $53.2 \pm 13.7$ years; $82.8 \%$ had a family history of ADPKD and $32.5 \%$ had reached end-stage renal disease (ESRD). With respect to cardiovascular risk factors, $86.6 \%$ were hypertensive with a mean age at diagnosis of $36.9 \pm$ 12.9 years and hypertension was significantly more prevalent in males. In addition, $19.6 \%$ of the subjects were obese, $20.8 \%$ were smokers, $8.7 \%$ had diabetes, $45.7 \%$ had high cholesterol and $17.8 \%$ were sedentary. The most prevalent self-reported cardiovascular events were arrhythmias (25.9\%), evidence of peripheral vascular disease $(16.5 \%)$, heart valve problems (14.4\%), cardiac enlargement (9.5\%), stroke or cerebral bleeding (7.5\%), myocardial infarction (6\%) and brain aneurysm (5.0\%). The most commonly used antihypertensive medications were renin-angiotensin inhibitors used by $75 \%$ of
\end{abstract}

ADPKD patients. Older ADPKD patients and those at ESRD had a significantly higher incidence of cardiovascular events. Conclusion: These findings support the high prevalence of cardiovascular risk factors and events in ADPKD patients which contribute to a greater mortality risk. Due to the prevalence of cardiovascular risk factors in the ADPKD population, early diagnosis and clinical intervention are recommended.

Copyright $\odot 2012$ S. Karger AG, Basel

\section{Introduction}

Approximately 6 million Americans have chronic cardiovascular and kidney disease combined, resulting in an increasing epidemic of heart and kidney failure [1]. This morbid association represents unique challenges to the clinician. Approximately 600,000 Americans are affected with autosomal dominant polycystic kidney disease (ADPKD), with over 2000 patients starting dialysis every year [2]. Patients with ADPKD have an increased incidence of early onset hypertension, left ventricular hypertrophy (LVH) and cardiovascular abnormalities [3, 4]. The reported relative mortality rate in patients with ADPKD ranges between 1.6-fold [95\% confidence interval (CI) 1.3-2.0] and 3.2-fold higher (95\% CI 2-4.8) in comparison to the general population [5].

\section{KARGER}

Fax +4161306 1234 E-Mail karger@karger.ch www.karger.com

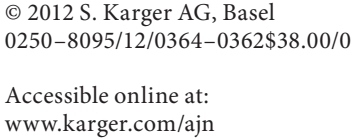

Robert W. Schrier

University of Colorado Denver, Division of Renal Diseases and Hypertension

Box C-281, 1270 East 19th, RC2 7th floor, Room 7001

Aurora, CO 80045 (USA)

E-Mail Robert.schrier@ucdenver.edu 
Table 1. Demographic characteristics of 419 survey respondents with ADPKD

\begin{tabular}{|c|c|c|}
\hline \multirow[t]{2}{*}{ Variable } & \multicolumn{2}{|c|}{ Patients } \\
\hline & $\mathrm{n}$ & $\%$ \\
\hline \multicolumn{3}{|l|}{ Sex } \\
\hline Male & 145 & 34.6 \\
\hline Female & 265 & 63.2 \\
\hline Not reported & 9 & 2.2 \\
\hline \multicolumn{3}{|l|}{ Ethnicity } \\
\hline Hispanic or Latino & 18 & 4.3 \\
\hline Not Hispanic or Latino & 369 & 88.1 \\
\hline Unknown or not reported & 32 & 7.6 \\
\hline \multicolumn{3}{|l|}{ Race } \\
\hline American Indian/Alaska native & 3 & 0.7 \\
\hline Asian & 3 & 0.7 \\
\hline Black or African American & 3 & 0.7 \\
\hline White & 381 & 93.6 \\
\hline More than one race & 12 & 3.0 \\
\hline Unknown or not reported & 17 & 4.1 \\
\hline Family history of ADPKD & 347 & 82.8 \\
\hline No & 37 & 8.8 \\
\hline Unknown & 35 & 8.4 \\
\hline ESRD & 136 & 32.5 \\
\hline No & 271 & 64.7 \\
\hline Unknown & 12 & 2.9 \\
\hline Hemodialysis or peritoneal dialysis & 83 & 19.8 \\
\hline No & 329 & 78.5 \\
\hline Unknown & 7 & 1.7 \\
\hline Transplantation & 117 & 27.9 \\
\hline No & 291 & 69.5 \\
\hline Unknown & 11 & 2.6 \\
\hline Dialysis and transplantation & 66 & 16 \\
\hline \multicolumn{3}{|l|}{ Preemptive transplantation } \\
\hline (never on dialysis) & 51 & 12.2 \\
\hline Mean age $\pm S D$, years ${ }^{1}$ & \multicolumn{2}{|c|}{$53.2 \pm 13.7$} \\
\hline
\end{tabular}

${ }^{1}$ Age at the time of survey available for 418 patients.
This study analyzed the cardiovascular events and risk factors in a large number of ADPKD patients according to gender, age, hypertension, cholesterol, smoking and end-stage renal disease (ESRD). This observational study was undertaken in an era in which the majority of patients were receiving RAAS inhibition.

\section{Methods}

Data Source and Study Population

We developed a 6-page survey that was distributed to 1,439 study subjects listed as having ADPKD in our database. The survey asked basic demographic questions and specific questions related to the occurrence of cardiovascular disease in ADPKD patients, including the occurrence of stroke, peripheral arterial disease, abdominal aortic aneurysm, angina pectoris, myocardial infarction, atrial or ventricular arrhythmias, LVH and cardiac valvular abnormalities. The survey also collected information regarding the presence and treatment of cardiovascular risk factors, including hyperlipidemia, smoking, diabetes mellitus, hypertension and medication use (see appendix).

The survey was sent in a single mailing (January 2011) with instructions and an envelope provided in which to return it. A total of $426(30 \%)$ subjects with ADPKD returned the survey completed; of these, 7 were from patients under the age of 18 years and these were excluded from the analysis.

Statistical Analysis

SAS version 9.3 PROC FREQ and PROC MEANS were used to obtain descriptive statistics for the surveys. The difference between the distribution of age categories for men and women was tested using a contingency table $\chi^{2}$ test. $\mathrm{p}<0.05$ was considered significant.

Proportions for demographics were calculated as a percentage of all respondents. Proportions for other tables were calculated as a percentage of those who responded to that question.

Because multiple outcomes were tested, $p$ values were adjusted using the Bonferroni method. Adjusted $\mathrm{p}$ values less than 0.0036 $(0.05 / 14)$ or unadjusted $p$ values $<0.05$ were considered significant. This adjustment corrects for the probability of getting a significant $\mathrm{p}$ value purely by chance.

\section{Results}

Descriptive Analysis of the Patients Who Responded

ADPKD patients who responded were female (63.2\%), nonHispanic (88.1\%) and white (93.6\%) (table 1). The mean age of the total group was $53.2 \pm 13.7$ years; $82.8 \%$ had a family history of ADPKD and $32.5 \%$ had reached ESRD. Analysis of cardiovascular risk factors (table 2) demonstrated that $86.6 \%$ had hypertension with a mean age of diagnosis of $36.9 \pm 12.9$ years with a significantly higher prevalence in males. In addition, $19.6 \%$ were obese, $20.8 \%$ were smokers, $8.7 \%$ had diabetes, $45.7 \%$ had high 
cholesterol and $17.8 \%$ were sedentary. The most prevalent self-reported cardiovascular events (table 3) were arrhythmias (25.9\%) with a mean age of diagnosis of 43.3 \pm 16.4 years, evidence of peripheral vascular disease (16.5\%; mean age of diagnosis $45 \pm 13$ years), heart valve problems (14.4\%; mean age of diagnosis $41.2 \pm 16.5$ years), cardiac enlargement (9.5\%; mean age of diagnosis $42.6 \pm 13.9$ years), stroke or cerebral bleeding (7.5\%; mean age of diagnosis $50.8 \pm 13.4$ years), myocardial infarction (6\%; mean age of diagnosis $53.4 \pm 9.6$ years) and brain aneurysm (5.0\%; mean age of diagnosis $43.4 \pm 13.7$ years). Angiotensin-converting enzyme inhibitors (ACEIs) and angiotensin receptor blockers (ARBs) were used in $75 \%$ of hypertensive ADPKD patients (table 4). Statins and antiplatelet medications (aspirin) were used in 11 and $22.5 \%$, respectively.

\section{Subgroup Analysis}

Demographic parameters or cardiovascular risk factors were not significantly different between males and females (table 5). The occurrence of reported heart attacks was significantly higher in males (11.4\%) than females (3.1\%) (adjusted p value of 0.0136) (table 4).

ADPKD respondents over the age of 45 years were significantly more likely to report hypertension and high cholesterol than those 45 years or younger (table 6). Cardiovascular events were higher in older ADPKD respondents but did not reach significance (table 6).

ADPKD respondents with ESRD were significantly more likely to report diabetes, hypertension and high cholesterol levels (table 7). They also reported a significantly higher incidence of stroke or cerebral bleeding, heart attack and cardiac enlargement (table 7).

\section{Discussion}

The most common extra-renal complications that contribute to morbidity and mortality in ADPKD patients are of a cardiovascular nature [4]. Hypertension is the most frequent cardiovascular complication and contributes to both an increased incidence of cardiovascular mortality and a faster progression to $\operatorname{ESRD}[6,11,12]$. Hypertension develops early in the course of ADPKD [13] and occurs in $50-70 \%$ of ADPKD patients with normal kidney function $[14,15]$. We previously reported a median age at diagnosis for hypertension in ADPKD of 32 years in males and 34 years in females [16]. The current results support the presence of early hypertension in $\mathrm{AD}$ $\mathrm{PKD}$. Hypertension is a widespread feature of this disease
Table 2. Incidence of cardiovascular risk factors in 419 survey respondents with ADPKD

\begin{tabular}{lrr}
\hline Variable & \multicolumn{2}{c}{ Patients } \\
\cline { 2 - 3 } & $\mathrm{n}$ & \multicolumn{1}{c}{$\%$} \\
\hline Obesity (BMI $\geq 30)$ & $77 / 392$ & 19.6 \\
Ever smoked & $156 / 412$ & 37.9 \\
Current Smoker & $32 / 154$ & 20.8 \\
Diabetes & $36 / 412$ & 8.7 \\
Hypertension & $356 / 411$ & 86.6 \\
High cholesterol & $188 / 411$ & 45.7 \\
Sedentary & $73 / 411$ & 17.8 \\
\hline
\end{tabular}

Table 3. Prevalence of cardiovascular events of 419 survey respondents with ADPKD

\begin{tabular}{|c|c|c|c|}
\hline \multirow[t]{2}{*}{ Variable } & \multicolumn{2}{|l|}{ Patients } & \multirow{2}{*}{$\begin{array}{l}\text { Mean age at } \\
\text { diagnosis } \\
\pm \mathrm{SD}\end{array}$} \\
\hline & $\mathrm{n}$ & $\%$ & \\
\hline Stroke or cerebral bleeding & $31 / 412$ & 7.5 & $50.8 \pm 13.4$ \\
\hline Brain aneurysm & $20 / 397$ & 5.0 & $43.4 \pm 13.7$ \\
\hline Circulation problems in legs & $66 / 400$ & 16.5 & $45 \pm 13$ \\
\hline Abdominal aortic aneurysm & 3/397 & 0.8 & $35.7 \pm 26.8$ \\
\hline Angina & $13 / 399$ & 3.3 & $48.9 \pm 15.9$ \\
\hline Heart attack & $24 / 399$ & 6 & $53.4 \pm 9.6$ \\
\hline Irregular heart beat (arrhythmia) & $103 / 398$ & 25.9 & $43.3 \pm 16.4$ \\
\hline Enlarged heart & $38 / 400$ & 9.5 & $42.6 \pm 13.9$ \\
\hline Heart valve problem & $57 / 397$ & 14.4 & $41.2 \pm 16.5$ \\
\hline Heart surgery & $23 / 393$ & 5.9 & $50.7 \pm 11.9$ \\
\hline Angioplasty & $4 / 23$ & 17.4 & \\
\hline Stents & $8 / 23$ & 34.8 & \\
\hline Angioplasty + stents & $3 / 23$ & 13 & \\
\hline Coronary bypass & $4 / 23$ & 17.4 & \\
\hline Cardiac valve surgery & $4 / 23$ & 17.4 & \\
\hline
\end{tabular}

and has been reported in up to $80 \%$ of ADPKD patients with ESRD on dialysis [17]. Thus, the main and most effective therapy in ADPKD remains control of hypertension primarily by including RAAS inhibition $[7,8]$. For the definitive answer of whether treatment with either ACEIs and/or ARBs results in a decreased rate of renal disease progression in ADPKD, we await the results of the HALT-PKD (Halt Progression of PKD) study [18]. However, the control of hypertension in ADPKD patients is important as it is a specific risk factor for intracerebral hemorrhage and aneurysm ruptures [19].

Our study demonstrates a high prevalence of cardiovascular risk factors including hypertension, obesity, diabetes and hypercholesterolemia in an ADPKD popula- 
Table 4. Use of antihypertensive drugs among 419 survey respondents with ADPKD

\begin{tabular}{|c|c|c|c|c|c|c|}
\hline \multirow[t]{3}{*}{ Drug } & \multicolumn{6}{|c|}{ ADPKD patients } \\
\hline & \multicolumn{2}{|c|}{ hypertensive } & \multicolumn{2}{|c|}{ nonhypertensive } & \multicolumn{2}{|l|}{ all } \\
\hline & $\mathrm{n}$ & $\%$ & $\mathrm{n}$ & $\%$ & $\mathrm{n}$ & $\%$ \\
\hline Diuretics & $78 / 333$ & 23.4 & $1 / 53$ & 1.9 & $79 / 387$ & 20.4 \\
\hline Sympathetic blocking agents & $92 / 329$ & 28 & $2 / 54$ & 3.7 & $94 / 385$ & 24.4 \\
\hline Vasodilators & $14 / 331$ & 4.2 & $1 / 53$ & 1.9 & $15 / 387$ & 3.9 \\
\hline Calcium channel blockers & $87 / 330$ & 26.4 & $0 / 54$ & 0 & $87 / 386$ & 22.5 \\
\hline ACEIs & $155 / 331$ & 46.8 & $6 / 54$ & 11.1 & $161 / 387$ & 41.6 \\
\hline ARBs & $92 / 331$ & 27.8 & $2 / 51$ & 3.9 & $94 / 384$ & 24.5 \\
\hline
\end{tabular}

Table 5. Analysis of cardiovascular risk factors and events by gender among 419 survey respondents with ADPKD

\begin{tabular}{|c|c|c|c|c|c|c|}
\hline \multirow[t]{2}{*}{ Variable } & \multicolumn{2}{|l|}{ Male } & \multicolumn{2}{|l|}{ Female } & \multirow[t]{2}{*}{$\mathrm{p}$ value ${ }^{\mathrm{a}}$} & \multirow{2}{*}{$\begin{array}{l}\text { Adjusted } \\
\mathrm{p} \text { value }\end{array}$} \\
\hline & $\mathrm{n}$ & $\%$ & $\mathrm{n}$ & $\%$ & & \\
\hline Obesity (BMI $\geq 30)$ & $33 / 140$ & 23.6 & $44 / 248$ & 17.7 & 0.1668 & 1 \\
\hline Current smoker & $9 / 60$ & 15.0 & $22 / 91$ & 24.2 & 0.1719 & 1 \\
\hline Diabetes & $12 / 144$ & 8.3 & $23 / 264$ & 8.7 & 0.8961 & 1 \\
\hline Hypertension & $127 / 143$ & 88.8 & $225 / 264$ & 85.2 & 0.3127 & 1 \\
\hline High cholesterol & $68 / 143$ & 47.6 & $119 / 264$ & 45.1 & 0.6322 & 1 \\
\hline Stroke or cerebral bleeding & $10 / 144$ & 6.9 & $20 / 144$ & 7.6 & $0.8154^{\mathrm{a}}$ & 1 \\
\hline Brain aneurysm & $5 / 138$ & 3.6 & $14 / 255$ & 5.5 & $0.4101^{\mathrm{a}}$ & 1 \\
\hline Abdominal aortic aneurysm & $2 / 138$ & 1.5 & $1 / 255$ & 0.4 & $0.2808^{\mathrm{b}}$ & 1 \\
\hline Angina & $8 / 140$ & 5.7 & $5 / 255$ & 2.0 & $0.0726^{\mathrm{b}}$ & 1 \\
\hline Heart attack & $16 / 140$ & 11.4 & $8 / 255$ & 3.1 & $0.0010^{\mathrm{a}}$ & 0.0136 \\
\hline Irregular heart beat (arrhythmia) & $32 / 139$ & 23.0 & $71 / 255$ & 27.8 & $0.2980^{\mathrm{a}}$ & 1 \\
\hline Enlarged heart & $21 / 140$ & 15.0 & $17 / 256$ & 6.6 & $0.0069^{\mathrm{a}}$ & 0.0971 \\
\hline Heart valve problem & $17 / 138$ & 12.3 & $40 / 255$ & 15.7 & $0.3655^{\mathrm{a}}$ & 1 \\
\hline
\end{tabular}

${ }^{\mathrm{a}} \chi^{2}$ test. ${ }^{\mathrm{b}}$ Fisher's exact test.

tion. In a previous study, $22 \%$ of ADPKD patients (age $35.9 \pm 11.1$ years) with normal kidney function also fulfilled the International Diabetes Federation criteria of metabolic syndrome [20].

$\mathrm{LVH}$ is a significant risk factor for cardiovascular morbidity and mortality and a common finding in hypertensive and even normotensive ADPKD patients [21-24]. However, a recent study in ADPKD patients with preserved renal function reported a prevalence of $\mathrm{LVH}$ of $3.9 \%$ [25]. Increased LV mass index does occur in children and young adults with ADPKD [13,26-28]. The early onset of hypertension in ADPKD may be associated with $\mathrm{LVH}$ in nearly $50 \%$ of ADPKD patients by their 40 s [22]. Increased LV mass index has been found to be associated with poor renal and overall outcomes in ADPKD patients
[12], and a significant correlation between hypertension and increased LV mass index has been demonstrated in both children and adult patients [13, 26-28]. RAAS inhibition in hypertensive ADPKD patients has led to the longterm reversal of LVH $[29,30]$. This finding was significantly greater in association with a rigorous control of blood pressure ( $<120 / 80 \mathrm{~mm} \mathrm{Hg}$ ) in ADPKD patients [30].

Structural cardiac abnormalities are found more often in ADPKD patients than in non-ADPKD family members or in normal controls [31]. A prospective echocardiographic study in ADPKD subjects found mitral valve prolapse in $26 \%$ and mitral regurgitation in 31\% [27]. Tricuspid regurgitation and aortic regurgitation were also found, in $15 \%$ and $8 \%$, respectively [29]. In our study, overall heart valve problems were found in $14.4 \%$ of patients. 
Table 6. Analysis of cardiovascular risk factors and events by age among 419 survey respondents with ADPKD

\begin{tabular}{|c|c|c|c|c|c|c|}
\hline \multirow[t]{2}{*}{ Variable } & \multicolumn{2}{|c|}{ Patients $\leq 45$ years } & \multicolumn{2}{|c|}{ Patients $>45$ years } & \multirow[t]{2}{*}{ p value ${ }^{a}$} & \multirow{2}{*}{$\begin{array}{l}\text { Adjusted } \\
\text { p value }\end{array}$} \\
\hline & $\mathrm{n}$ & $\%$ & $\mathrm{n}$ & $\%$ & & \\
\hline Obesity (BMI $\geq 30$ ) & $17 / 86$ & 19.8 & $60 / 305$ & 19.7 & 0.9843 & 1 \\
\hline Current smoker & $11 / 28$ & 39.3 & $21 / 125$ & 16.8 & 0.0082 & 0.1146 \\
\hline Diabetes & $3 / 91$ & 3.3 & $33 / 320$ & 10.3 & 0.0367 & 0.5140 \\
\hline Hypertension & $59 / 91$ & 64.8 & $296 / 319$ & 92.8 & $<0.0001$ & $<0.0001$ \\
\hline High cholesterol & $14 / 91$ & 15.4 & $174 / 319$ & 54.6 & $<0.0001$ & $<0.0001$ \\
\hline Stroke or cerebral bleeding & $1 / 92$ & 1.1 & $30 / 319$ & 9.4 & $0.0078^{\mathrm{a}}$ & 0.1089 \\
\hline Brain aneurysm & $2 / 90$ & 2.2 & $18 / 306$ & 5.9 & $0.1634^{\mathrm{a}}$ & 1 \\
\hline Abdominal aortic aneurysm & $0 / 92$ & 0 & $3 / 304$ & 1.0 & $\mathrm{n} / \mathrm{a}$ & 1 \\
\hline Angina & $1 / 92$ & 1.1 & $12 / 306$ & 3.9 & $0.3141^{\mathrm{b}}$ & 1 \\
\hline Heart attack & $1 / 92$ & 1.1 & $23 / 306$ & 7.5 & $0.0231^{\mathrm{a}}$ & 0.3236 \\
\hline Irregular heart beat (arrhythmia) & $14 / 91$ & 15.4 & $89 / 306$ & 29.1 & $0.0089^{\mathrm{a}}$ & 0.1239 \\
\hline Enlarged heart & $2 / 91$ & 2.2 & $36 / 308$ & 11.7 & $0.0067^{\mathrm{a}}$ & 0.0943 \\
\hline Heart valve problem & $8 / 91$ & 8.8 & $49 / 305$ & 16.1 & $0.0828^{\mathrm{a}}$ & 1 \\
\hline
\end{tabular}

Table 7. Analysis of cardiovascular risk factors and events by gender among 419 ADPKD survey respondents with and without ESRD

\begin{tabular}{|c|c|c|c|c|c|c|}
\hline \multirow[t]{2}{*}{ Variable } & \multicolumn{2}{|c|}{ Patients with ESRD } & \multicolumn{2}{|c|}{ Without ESRD } & \multirow[t]{2}{*}{$\mathrm{p}$ value $\mathrm{a}^{\mathrm{a}}$} & \multirow{2}{*}{$\begin{array}{l}\text { Adjusted } \\
\text { p value }\end{array}$} \\
\hline & $\mathrm{n}$ & $\%$ & $\mathrm{n}$ & $\%$ & & \\
\hline Obesity (BMI $\geq 30)$ & $21 / 129$ & 16.3 & $56 / 257$ & 21.8 & 0.2012 & 1 \\
\hline Current smoker & $8 / 57$ & 14.0 & $24 / 94$ & 25.5 & 0.0938 & 1 \\
\hline Diabetes & $22 / 135$ & 16.3 & $13 / 270$ & 4.8 & 0.0001 & 0.0015 \\
\hline Hypertension & $132 / 135$ & 97.8 & $218 / 269$ & 81.0 & $<0.0001$ & $<0.0001$ \\
\hline High cholesterol & $86 / 134$ & 64.2 & $97 / 270$ & 35.9 & $<0.0001$ & $<0.0001$ \\
\hline Stroke or cerebral bleeding & $20 / 135$ & 14.8 & $10 / 271$ & 6.7 & $<0.0001^{\mathrm{a}}$ & 0.0008 \\
\hline Brain aneurysm & $12 / 131$ & 9.2 & $8 / 259$ & 3.1 & $0.0102^{\mathrm{a}}$ & 0.1434 \\
\hline Abdominal aortic aneurysm & $2 / 131$ & 1.5 & $1 / 259$ & 0.4 & $0.2621^{\mathrm{b}}$ & 1 \\
\hline Angina & $8 / 132$ & 6.1 & $5 / 260$ & 1.9 & $0.0387^{\mathrm{b}}$ & 0.5417 \\
\hline Heart attack & $16 / 133$ & 12.0 & $8 / 259$ & 3.1 & $0.0005^{\mathrm{a}}$ & 0.0066 \\
\hline Irregular heart beat (arrhythmia) & $44 / 133$ & 33.1 & $57 / 258$ & 22.1 & $0.0187^{\mathrm{a}}$ & 0.2614 \\
\hline Enlarged heart & $21 / 132$ & 15.9 & $16 / 261$ & 6.1 & $0.0017^{\mathrm{a}}$ & 0.0240 \\
\hline Heart valve problem & $23 / 130$ & 17.7 & $32 / 260$ & 12.3 & $0.1498^{\mathrm{a}}$ & 1 \\
\hline
\end{tabular}

${ }^{\mathrm{a}} \chi^{2}$ test. ${ }^{\mathrm{b}}$ Fisher's exact test.

The occurrence rate of coronary events, such as angina, myocardial infarction, and the need for coronary revascularization in ADPKD patients with normal renal function has not been previously reported in the literature. Our survey reported that $3.3 \%$ of respondents had angina, $6 \%$ had suffered a heart attack and $5.9 \%$ had undergone angioplasty, angioplasty and stent or cardiac valve surgery. The mean age for heart surgery was 50.7 \pm 11.9 years. ADPKD patients with ESRD had less coronary events than matched ESRD patients of other causes
$[32,33]$. This has been attributed to less severe anemia in ADPKD patients $[32,33]$, which is probably due to increased endogenous erythropoietin production [34].

Arterial aneurysms, particularly intracranial aneurysms, are more prevalent in $\mathrm{ADPKD}$ patients than in the general population (4.0-11.7 vs. $1.0 \%)$ [35, 36]. Moreover, it has been suggested that ADPKD is a risk factor for coronary artery aneurysms [37]. Abdominal aortic aneurysm also appears to be more prevalent in ADPKD patients [38-40], although in our cohort, the incidence was 
actually very low (0.8\%). However, a tendency towards larger aortic diameters in ADPKD patients compared to a control population has previously been reported [39].

The other major vascular abnormality in ADPKD is intracranial aneurysms (ICA). The prevalence ranges from $5 \%$ in patients with no family history of ICA to $21 \%$ in those with a positive family history of ICA rupture [32, $35,41]$. The prevalence may be even higher in ADPKD patients on dialysis, as observed in our study. An occurrence rate of both asymptomatic and ruptured ICA of 33.3\% has been reported in ADPKD patients with ESRD [42]. Another study [43] found no difference in incidence of cerebrovascular accidents between ADPKD patients on dialysis and a non-PKD dialysis patient population. Only $25-50 \%$ of cerebrovascular accidents in ADPKD patients have been reported to result from ICA rupture $[6,44]$. In our cohort, brain aneurysm and stroke prevalence or intracerebral bleeding were 5 and $7.5 \%$, respectively. ICA rupture accounts for a $35-55 \%$ risk of combined morbidity and mortality $[19,45]$, so identification and screening of patients at risk for developing symptomatic ICA are recommended. Systematic screening of ICA with 3-dimensional magnetic resonance angiography (MRA) is recommended for ADPKD patients, particularly for adults ( $\geq 30$ years), with a positive family history of hemorrhagic stroke or ICA, those undergoing major surgery with potential hemodynamic instability and those with high-risk occupations [46, 47]. It has been recommended that MRA be conducted every 5 years if initially negative and every $2-3$ years if positive [46]. However, recent data support a requirement for less screening for ICAs in ADPKD patients and therefore widespread screening is not indicated [48].

Patients with non-PKD chronic kidney disease demonstrate significantly increased cardiovascular events and risk factors [49]. However, ADPKD is unique, due to the early occurrence of hypertension, heart valve problems and ICA. As expected, older ADPKD patients and those with ESRD are at a higher risk for cardiovascular events; male gender, however, may be losing its importance as a risk factor. The early and effective treatment of hypertension in ADPKD is critical for the prevention of cardiovascular events in ADPKD.

\section{Conclusion}

There are intrinsic limitations to the survey-based nature of this study and the reported frequencies may be underestimated. Nevertheless, these findings confirm the high prevalence of cardiovascular risk factors and events in ADPKD patients which are associated with an increased risk for mortality. Moreover, older ADPKD subjects and those with ESRD had an increased risk for cardiovascular events, and this increased morbidity and mortality. Due to the prevalence and early onset of cardiovascular risk factors in the ADPKD population, early diagnosis and intervention by aggressively treating blood pressure in ADPKD patients is considered important for the prevention of $\mathrm{LVH}$, cardiovascular complications and mortality.

\section{Acknowledgements}

I.H. received an International Society of Nephrology-funded fellowship and support from the Laboratory of Kidney Pathology (LR00SP01-Pr Ben Maiz Hedi), Charles Nicolle Hospital, Tunis, Tunisia.

P.M. was supported in part by NIH/NCRR Colorado CTSI, Grant No. UL1 RR025780.

The research was supported by grant Nos. M01RR00051, M01RR00069 General Research Centers Program, National Center for Research Resources (NCRR)/NIH, DK34039 from $\mathrm{NIH}(\mathrm{NIDDK})$ and by the Zell Family Foundation. The content of this publication are the authors sole responsibility and do not necessarily represent the official NIH views.

\section{Appendix}

Survey on Polycystic Kidney Disease

Please mark answers with an X or fill in the information in the box as indicated.

By returning this form, I indicate my consent to participate in this survey.

Information will be kept strictly confidential.

Feel free to attach a sheet of paper if needed to clarify an answer.

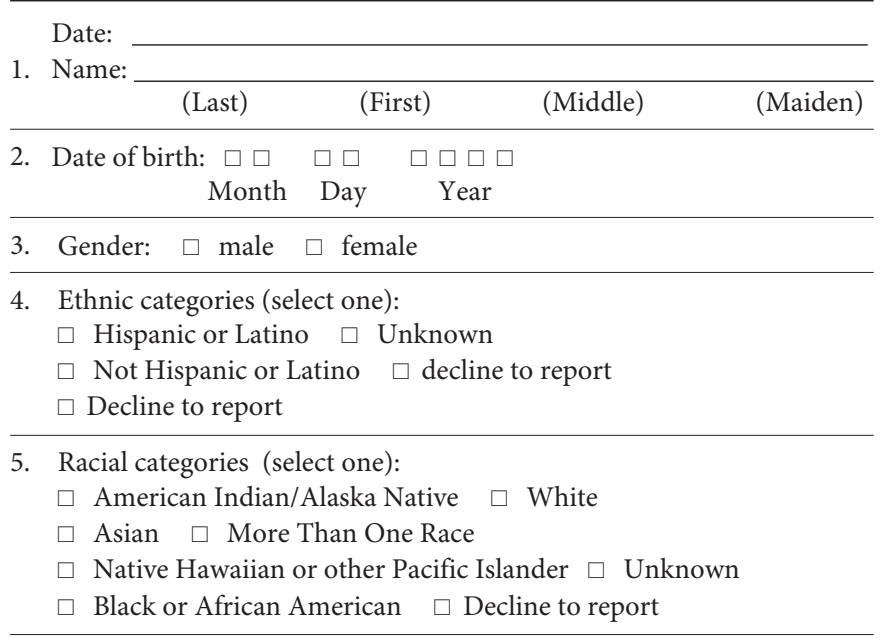


6. Do you have other family members with PKD? $\square$ Yes $\square$ No $\square$ Unknown

7. Have you had either hemodialysis or peritoneal dialysis treatment? $\square$ Yes $\square$ No

If yes, what was your age at the time you had your first dialysis treatment? $\square \square$

8. Have you received a kidney transplant? $\square$ Yes $\square$ No If yes, what was your age at the time of your first transplant? $\square \square$

9. Weight (pounds) $\square \square \square$ Height (feet) $\square \square \square$

10. Have you ever smoked Cigarettes or Cigars: $\square$ Yes $\square$ No If yes: How many packs/day: $\square \square$ Number of years you have smoked: $\square \square$ Do you still smoke? $\square$ Yes $\square$ No

11. Have you ever been told by a doctor that you have diabetes? $\square$ Yes $\square$ No If yes, what was your age at diagnosis? $\square \square$ If yes, Type: $\square 1 \quad \square 2 \quad \square$ Gestational $\square$ Unknown (only during pregnancy) If yes, initial treatment: $\square$ Diet $\square$ Medication $\square$ Insulin injection If yes for medication(s), which diabetes medication(s) do you take? Current diabetes treatment (if different from above):

$\square$ Diet $\square$ Medication $\square$ Insulin injection What was your age when you began your current treatment? $\square \square$ If yes for medication(s), which diabetes medication(s) do you currently take?

12. Have you ever been told by a doctor that you have high blood pressure $\square$ Yes $\square$ No If yes, what was your age at diagnosis? $\square \square$ Have you been on medication for high blood pressure? $\square$ Yes $\square$ No If yes, which high blood pressure medication(s) do you take?

13. Have you ever been told by a doctor that you have high cholesterol? $\square$ Yes $\square$ No If yes, what was your age at diagnosis? $\square \square$ Current treatment: $\square$ Diet $\square$ Medication If yes for medication, which high cholesterol medication(s) do you take?

14. Do you exercise? $\square$ Yes $\square$ No If yes, how many hours/week? $\square \square$ What type of exercise? $\square$ Walking $\square$ Running $\square$ Biking $\square$ Other

15. Have you ever been told by a doctor that you had a stroke or bleeding in your head?

$\square$ Yes $\square$ No If yes, what was your age at diagnosis? $\square \square$

What was the problem (Mark all that apply)?

$\square$ Symptoms of stroke lasting less than 24 hours

$\square$ Stroke $\square$ Bleeding $\square$ Ruptured aneurysm

16. Have you ever been told by a doctor that you have a brain aneurysm? $\square$ Yes $\square$ No If yes, what was your age at diagnosis? $\square \square$ If yes, have you ever had surgery for your aneurysm? $\square$ Yes

17. Has anyone in your family been told by a doctor that they have a brain aneurysm or had a ruptured aneurysm in their head?

$\square$ Yes $\square$ No $\square$ Unknown

If yes, what was their age at diagnosis? $\square \square$

How are they related to you?

If yes, what was their age at diagnosis? $\square \square$

How are they related to you?

If yes, what was their age at diagnosis? $\square \square$

How are they related to you?
18. Have you ever had circulation problems in your legs?

$\square$ Yes $\square$ No

If yes, what was your age when this first occurred? $\square \square$

19. Have you ever been told by a doctor that you had an abdominal aortic aneurysm?

$\square$ Yes $\square$ No If yes, what was your age at diagnosis? $\square \square$

20. Have you ever been told by a doctor that you have Angina? $\square$ Yes $\square$ No If yes, what was your age at diagnosis? $\square \square$

21. Have you ever been told by a doctor that you had a heart attack? $\square$ Yes $\square$ No If yes, what was your age at diagnosis? $\square \square$

22. Have you ever been told by a doctor that you have an irregular heart beat?

$\square$ Yes $\square$ No If yes, what was your age at diagnosis? $\square \square$

23. Have you ever been told by a doctor that you have an enlarged heart? $\square$ Yes $\square$ No If yes, what was your age at diagnosis? $\square \square$

24. Have you ever been told by a doctor that you have a heart valve problem?

$\square$ Yes $\square$ No If yes, what was your age at diagnosis? $\square \square$

25. Have you ever had heart surgery? $\square$ Yes $\square$ No If yes: $\square$ Angioplasty $\square$ Stents $\square$ Angioplasty + Stent $\square$ Coronary bypass

If yes, what was your age at surgery? $\square \square$

26. If working, how many days have you missed work in the last year due to symptoms related to your PKD?

27. Have you ever been told by a doctor that you have osteoporosis? $\square$ Yes $\square$ No If yes, what was your age at diagnosis? $\square \square$

28. Have you ever been told by a doctor that you have low vitamin $\mathrm{D}$ ? $\square$ Yes $\square$ No If yes, what was your age at diagnosis? $\square \square$

29. Have you ever been told by a doctor that you had kidney stones, or other problems from kidney stones?

$\square$ Yes $\square$ No If yes, what was your age at diagnosis? $\square \square$

$\square$ In one kidney $\square$ In both kidneys

How were the kidney stones treated?

$\square$ Surgery $\square$ Medication $\square$ Other

If yes for medication, which medication(s) did you take for your kidney stones?

30. What were your symptoms of kidney stones (mark all that apply):

$\square$ Back pain $\square$ Flank/side pain $\square$ Abdominal/stomach pain

$\square$ Bloody urine $\square$ A doctor found blood in my urine

$\square$ Kidney infection $\quad \square$ Abnormal laboratory or radiology results

31. Do you know what kind of stone you had?

$\square$ Uric acid stone $\square$ Calcium-containing stone $\square$ Unknown

32. Any other medical conditions not mentioned above?

33. Are you currently taking prescription or over the counter medication(s) or vitamins?

$\square$ Yes $\square$ No, not currently taking medication $\quad \square$ Decline to report Please list all current medicine(s) and the first date on which you started taking this medicine:

Name of medication:

Date began taking medication:

Name of medication:

Date began taking medication: 


\section{References}

1 McCullough PA: Scope of cardiovascular complications in patients with kidney disease. Ethn Dis 2002;12:44-48.

2 U.S. Renal Data System: USRDS 2011 Annual Data Report, 2011.

- 3 Schrier RW: Optimal care of autosomal dominant polycystic kidney disease patients. Nephrology 2006;11:124-130.

-4 Ecder T, Schrier RW: Cardiovascular abnormalities in autosomal-dominant polycystic kidney disease. Nat Rev Nephrol 2009;5:221228.

5 Florijin KW, Noteboom WM, Van Saase JL, Chang PC, Breuning MH, Vandenbroucke JP: A century of mortality in five large families with polycystic kidney disease. Am J Kidney Dis 1995;25:370-374.

-6 Fick GM, Johnson AM, Hammond WS, Gabow PA: Causes of death in autosomal dominant polycystic kidney disease. J Am Soc Nephrol 1995;5:2048-2056.

-7 Schrier RW, McFann KK, Johnson AM: Epidemiological study of kidney survival in autosomal dominant polycystic kidney disease. Kidney Int 2003;63:678-685.

-8 Patch C, Charlton J, Roderick PJ, Gulliford MC: Use of antihypertensive medications and mortality of patients with autosomal dominant polycystic kidney disease: a population-based study. Am J Kidney Dis 2011;57: 856-862.

-9 Orskov B, Rømming Sørensen V, Feldt-Rasmussen B, Strandgaard S: Improved prognosis in patients with autosomal dominant polycystic kidney disease in Denmark. Clin J Am Soc Nephrol 2010;5:2034-2039.

-10 Ecder T, Edelstein CL, Fick-Brosnahan GM, Johnson AM, Chapman AB, Gabow PA, Schrier RW: Diuretics versus angiotensinconverting enzyme inhibitors in autosomal dominant polycystic kidney disease. Am J Nephrol 2001;21:98-103.

11 Iglesias C, Torres V, Offord K, Holley K, Beard C, Kurland L: Epidemiology of adult polycystic kidney disease, Olmsted County, Minnesota: 1935-1980. Am J Kidney Dis 1983;2:630 -639.

12 Gabow PA, Johnson AM, Kaehny WD, Kimberling WJ, Lezotte DC, Duley IT, Jones RH: Factors affecting the progression of renal disease in autosomal-dominant polycystic kidney disease. Kidney Int 1992;41:13111319.

- 13 Zeier M, Geberth S, Schmidt KG, Mandelbaum A, Ritz E: Elevated blood pressure profile and left ventricular mass in children and young adults with adult polycystic kidney disease. J Am Soc Nephrol 1993;3:1451-1457.

14 Chapman AB, Schrier RW: Pathogenesis of hypertension in autosomal dominant polycystic kidney disease. Semin Nephrol 1991; 11:653-660
15 Ecder T, Schrier RW: Hypertension in autosomal-dominant polycystic kidney disease: early occurrence and unique aspects. J Am Soc Nephrol 2001;12:194-200.

-16 Schrier RW, Johnson AM, McFann K, Chapman AB: The role of parental hypertension in the frequency and age of diagnosis of hypertension in offspring with autosomaldominant polycystic kidney disease. Kidney Int 2003;64:1792-1799.

17 Milutinovic J, Fialkow PJ, Agodoa LY, Phillips PA, Rudd TG, Bryant JI: Adult polycystic kidney disease symptoms and clinical findings. Q J Med 1984;53:511-522.

18 Chapman AB, Torres VE, Perrone RD, Steinman TI, Bae KT, Miller JP, Miskulin DC, Rahbari Oskoui F, Masoumi A, Hogan MC, Winklhofer FT, Braun W, Thompson PA, Meyers CM, Kelleher C, Schrier RW: The HALT polycystic kidney disease trials: design and implementation. Clin J Am Soc Nephrol 2010;5:102-109.

19 Chaveau D, Pirson Y, Verellen-Dumoulin C, Macnicol A, Gonzalo A, Grunfeld JP: Intracranial aneurysms in autosomal dominant polycystic kidney disease. Kidney Int 1994; 45:1140-1146.

20 Pietrzak-Nowacka M, Safranow K, Byra E, Bińczak-Kuleta A, Ciechanowicz A, Ciechanowski K: Metabolic syndrome components in patients with autosomal-dominant polycystic kidney disease. Kidney Blood Press Res 2009;32:405-410.

21 Koren MJ, Devereux RB, Casale PN, Savage DD, Laragh JH: Relationship of left ventricular mass and geometry to morbidity and mortality in uncomplicated essential hypertension. Ann Intern Med 1991;114:345-352.

22 Chapman AA: Left ventricular hypertrophy in autosomal dominant polycystic kidney disease. J Am Soc Nephrol 1997;8:1292-1297.

23 Saggar-Malik A, Missouris CG, Gill JS, Singer DR, Markandu ND, MacGregor GA: Left ventricular mass In normotensive subjects with autosomal dominant polycystic kidney disease. BMJ 1994;309:1617-1618.

-24 Bardaji A, Vea AM, Gutierrez C, Ridao C, Richart C, Oliver JA: Left ventricular mass and diastolic function in normotensive young adults with autosomal dominant polycystic kidney disease. Am J Kidney Dis 1998;32:970-975.

-25 Perrone RD, Abebe KZ, Schrier RW, Chapman AB, Torres VE, Bost J, Kaya D, Miskulin DC, Steinman TI, Braun W, Winklhofer FT, Hogan MC, Rahbari-Oskoui F, Kelleher C, Masoumi A, Glockner J, Halin NJ, Martin D, Remer E, Patel N, Pedrosa I, Wetzel LH, Thompson PA, Miller JP, Bae KT, HALT PKD Study Group, Meyers CM: Cardiac magnetic resonance assessment of left ventricular mass in autosomal dominant polycystic kidney disease. Clin J Am Soc Nephrol 2011;6:2508-2515.
26 Ivy DD, Shaffer EM, Johnson AM, Kimberling WJ, Dobin A, Gabow PA: Cardiovascular abnormalities in children with autosomal dominant polycystic kidney disease. J Am Soc Nephrol 1995;5:2032-2036.

27 Bardaji A, Martinez-Vea A, Valero A, Gutierrez C, Garcia C, Ridao C, Oliver JA, Richart $\mathrm{C}$ : Cardiac involvement in autosomal dominant polycystic kidney disease: a hypertensive heart disease. Clin Nephrol 2002;56: 211-220.

28 Cadnapaphornchai MA, McFann K, Strain JD, Masoumi A, Schrier RW: Increased left ventricular mass in children with autosomal dominant polycystic kidney disease and borderline hypertension. Kidney Int 2008;74: 1192-1196.

29 Ecder T, Edelstein CL, Chapman AB, Johnson AM, Tison L, Gill EA, Brosnahan GM, Schrier RW: Reversal of left ventricular hypertrophy with angiotensin converting enzyme inhibition in hypertensive patients with autosomal dominant polycystic kidney disease. Nephrol Dial Transplant 1999;14: 1113-1116.

30 Schrier R, McFann K, Johnson A, Chapman A, Edelstein C, Brosnahan G, Ecder T, Tison L: Cardiac and renal effects of standard versus rigorous blood pressure control in autosomal-dominant polycystic kidney disease: results of a seven-year prospective randomized study. J Am Soc Nephrol 2002;13:17331739.

- 31 Hossack KF, Leddy CL, Johnson AM, Schrier RW, Gabow PA: Echocardiographic findings in autosomal dominant polycystic kidney disease. N Engl J Med 1988;319:907-912.

- 32 Pirson Y, Christophe JL, Goffin E: Outcome of renal replacement therapy in adult polycystic kidney disease. Nephrol Dial Transplant 1996;11:24-28.

33 Ritz E, Zeier M, Schneider P, Jones E: Cardiovascular mortality of patients with polycystic kidney disease on dialysis: is there a lesson to learn? Nephron 1994;66:125-128.

- 34 Verdalles U, Abad S, Vega A, Ruiz Caro C, Ampuero J, Jofre R, Lopez-Gomez JM: Factors related to the absence of anemia in hemodialysis patients. Blood Purif 2011;32:69-74.

- 35 Chapman AB, Rubinstein D, Hughes R, Stears JC, Earnest MP, Johnson AM, Gabow PA, Kaehny WD: Intracranial aneurysms in autosomal dominant polycystic kidney disease. N Engl J Med 1992;327:916-920.

36 Ruggleri PM, Poulos N, Masaryk TJ, Ross JS, Obuchowski NA, Awad IA, Braun WE, Nally J, Lewin JS, Modic MT: Occult intracranial aneurysms in polycystic kidney disease: screening with MR angiography. Radiology 1994;191:33-39.

37 Hadimeri H, Lamm C, Nyberg G: Coronary aneurysms in patients with adult polycystic kidney disease. J Am Soc Nephrol 1998;9: 837-841. 
-38 Montoliu J, Torras A, Revert L: Polycystic kidneys and abdominal aortic aneurysms. Lancet 1980;1:1133-1134.

-39 Chapman AB \& Hilson AJW: Polycystic kidneys and abdominal aortic aneurysms. Lancet 1980;1:646-647.

-40 Torra R, Nicolau C, Badenas C, Brú C, Pérez L, Estivill X, Darnell A: Abdominal aortic aneurysms and adult polycystic kidney disease. J Am Soc Nephrol 1996;7:2483-2486.

-41 Huston J, Torres VE, Sullivan PP, Offord KP, Wiebers DO: Value of magnetic resonance angiography for the detection of intracranial aneurysms in autosomal dominant polycystic kidney disease. J Am Soc Nephrol 1993;3: 1871-1877.

-42 Konoshita T, Okamoto K, Koni I, Mabuchi $\mathrm{H}$ : Clinical characteristics of polycystic kidney disease with end-stage renal disease. Clin Nephrol 1998;50:113-118.
43 Christophe JL, Van Ypersele de Strihou C, Pirson Y: Complications of autosomal dominant polycystic kidney disease in 50 haemodialysed patients. A case-control study. Nephrol Dial Transplant 1996;11:1271-1276.

44 Zeier M, Geberth S, Ritz E, Jaeger T, Waldherr R: Autosomal dominant polycystic kidney disease - clinical problems. Nephron 1988;49:177-183.

45 Schievink WI, Torres VE, Piepgras DG Wiebers DO: Saccular intracranial aneurysms in autosomal dominant polycystic kidney disease. J Am Soc Nephrol 1992;3: 88-95.
46 Wiebers DO, Torres VE: Screening for unruptured intracranial aneurysms in autosomal dominant polycystic kidney disease. $\mathrm{N}$ Engl J Med 1992;327:953-955.

47 Xu HW, Yu SQ, Mei CL, Li MH: Screening for intracranial aneurysm in 355 patients with autosomal-dominant polycystic kidney disease. Stroke 2011;42:204-206.

-48 Irazabal MV, Huston J 3rd, Kubly V, Rossetti S, Sundsbak JL, Hogan MC, Harris PC, Brown RD Jr, Torres VE: Extended follow-up of unruptured intracranial aneurysms detected by presymptomatic screening in patients with autosomal dominant polycystic kidney disease. Clin J Am Soc Nephrol 2011; 6:1274-1285

49 Sarnak MJ: Cardiovascular complications in chronic kidney disease. Am J Kidney Dis 2003;41:11-17. 